\title{
Should intellectual property be disseminated by "forwarding" rejected letters without permission?
}

\author{
Vinod Kumar Gupta Dubai Police Medical Services, United Arab Emirates
}

\begin{abstract}
Substantive scientific letter writing is a cost-effective mode of complementing observational and experimental research. The value of such philosophically uncommitted and unsponsored well-balanced scientific activity has been relegated. Critical letter writing entails the abilities to: maintain rational scepticism; refuse to conform in order to explain data; persist in keeping common sense centre-stage; exercise logic to evaluate the biological significance of mathematical figures, including statistics, and the ability to sustain the will to share insights regarding disease mechanisms on an ostensibly lower research platform. During peer review, innovative letter writing may share the occasionally unfortunate fate of innovative research. Rejected scientific letters do not automatically lose copyright. Periodicals with high letter loads will see some valuable contributions wasted, but that is the price for maintaining autonomy in scientific publication. The scientific community is an integrated whole that must respect the rights of authors at all levels. Unauthorised forwarding of rejected letters sets the dangerous precedent of justifying unjust means.
\end{abstract}

Science and scientific publication are dealt with in the context - or absence ${ }^{1}$ - of a culture of mutual respect, the underlying philosophy being that, even if much of research activity is shoddy science and selfserving activity ${ }^{2}$ and there is premature pressure to publish or perish, the collective motivation of authors, reviewers, editors and publishers is furtherance of the human cause. However, the balance of power in this collective endeavour is (hopelessly?) skewed. Editorial fiat - largely linked to review/reviewer idiosyncrasy - and the rights of (would-be) authors form a constant boiling mixture, with the balance of power being largely in favour of the former. Review is essentially a subjective process that wields enormous power, can be hostile to the overthrowing of the current paradigm and might be least receptive to innovative science. ${ }^{3}$ Research, including review, is rarely (never?) an activity free of

\section{Key words}

Ethics; copyright violation; forwarding of rejected letters; scientific letter writing; scientific review. ideological and/or philosophical roots. The philosophical aspect and style of scientific writing or review is most often unconsciously imbibed by contemporary osmosis; unfortunately, the osmosis colours the individual in the hues of the extant scientific framework, rendering the scientist (author and/or reviewer) largely incapable of swimming against the current.

In the wake of an academic disgrace, ${ }^{4}$ I sent for publication a brief critical note on: the difficulty of maintaining academic integrity in our hedonistic society; the concentration of the collective soul on pence, bestowing respectability to matters fiscal; the unwavering overriding general focus on the quantitative; the limitations of negative restraints and confrontational ethics; the value of preserving empathy the jewel in the crown of the medical profession, and the danger of mind-paralyzing words such as "democracy" and "legal". The manuscript was rejected outright. The content of my para-scientific manuscript was doubtlessly non-conformist, enticing thinking along fresh avenues on issues long hallowed by capitalist tradition. The rejection of the content of the manuscript was inconsequential - a universal meeting of minds is neither possible nor always desirable. It is the contemplative difference in perceptions of existence that alone provokes progress. I was taken aback by the accompanying remarks in the rejection letter of the flagship periodical of the BMJ Publishing Group, the British Medical foumal. The corresponding editor completely disregarded my right over the fate of my manuscript and informed me that it would be "forwarded" to the authors of the piece to which I had referred. Can the respondent guarantee that those who will be so privileged will not use my thoughts and analyses to their advantage without acknowledging the source? Should I regard this unauthorised transfer as a favourable outcome for myself or for science or for the principles that underlie medical (and general) publication?

The $B M \mathcal{F}$ stands isolated in recently printing this "forwarding" policy in its instructions for letterwriters; to a less formidable and resourceful periodi$\mathrm{cal}$, the fear of potential litigation would have been sufficient deterrent. The Lancet, and other equally formidable transatlantic medical periodicals do not 
share this perception. What the management of the $B M \mathcal{F}$ have completely failed to grasp is the disincentive with which they have handicapped critical letter writers, who, of course, constitute the minority. The complexity of human and scientific motives is underscored by the recent $B M \mathcal{F}$ editorial highlighting the commonly disparaged role of letter writing in medical research. ${ }^{5}$ Critical letter writing is a forum to redress the disadvantages of technological dependence, ${ }^{6}$ investigational hubris, ${ }^{7}$ teleological neglect, ${ }^{8}$ and the flip-side of the universally hallowed scientific data that allows scientists to creep away from or create insoluble circular loops (of the hen-egg puzzle genre) in logic. Critical letter writing enables science (and scientists) to remain on the slippery slope of insight and common sense, by refusing to contort or conform in order to explain data and by introducing saltatory logic that promotes lateral thinking. Writing a substantive letter is not the same as writing a letter for the sake of debate; while the former shares insight, the latter is merely argumentative sustenance for controversy. Leading medical periodicals bemoan the runaway proliferation and lack of quality or genuine ideas in current biomedical publication as well as the absence of the readiness to make bold guesses..$^{10}$ Can it be conceivable that "forwarding" letters to the original authors - few of who ever acknowledge gaps in their own perception - will ensure better quality of medical writing? At the cutting edge of research, which is nebulous to all, who is qualified to judge what is substantive or not? Is it not counterproductive to shackle the very minds (the few imaginative biologically attuned scientists who carry the conviction to challenge figures/data) that might help to rationalise research through the relentless application of logic with the fear that their contribution might go unacknowledged?

Respected periodicals, being institutions within themselves, must guard against the emergence of Orwellian overbearance. Winston slaved anonymously for the Party, the perpetuation of which justified any means. ${ }^{11}$ Is the "forwarding" policy for letters the first salvo in the quest, that ultimately, individual authors will be counselled, even compelled, to do "what is good for society"? Ironically, this policy is an unconscious step towards the very anonymity that inspired the editorial. ${ }^{4}$ Abnegation of author prerogatives must never be condoned. To do so is perhaps the greatest moral setback for both the author and the community. It is fashionable to be concerned about patient rights, largely because of the fear of litigation. Must we take heed only because of the fear of the law (extrinsic, imposed) rather than take care for the sake of the universal code of righteousness (intrinsic, natural).

Justice is one of the moral pillars of medical ethics. ${ }^{12}$ In a world inundated with rhetoric, justice and righteousness are hopelessly obfuscated words, that do not stand universally on their own merit, but vary according to individual or collective perception.
The perennial guide in the right-versus-wrong debate is $\stackrel{3}{\stackrel{2}{\Omega}}$ the principle of mutual and/or reciprocal expectation. Would the editorial staff of the $B M \mathcal{Y}$ itself relish the prospect of such displacement of their own intellectual property? Even those who have been stung by $\overrightarrow{\bar{B}}$ editorial fiat ${ }^{13}$ or advocate the genre of medical letter writing ${ }^{5}$ have not yet been seized by this policy. 등 The philosophically uncommitted, unsponsored, $\frac{\bar{c}}{\bar{c}}$. unfinanced, substantive letter-writer, unworried $\vec{\otimes}$ about remaining unsung while working for the truth in a state of tranquillity beyond applause or financial os award (and not simply to notch up conventional $\vec{O}$ publications for career ascent), is an endangered, perhaps already extinct, species. Before inscribing this policy - which threatens even acknowledgment $\overline{3}$ of source - into tablets of stone, at the very least, the $\overparen{D}$ $B M F$ should conduct a survey of biologically attuned N rationalising letter-writers (in contrast to editorial- $\rightarrow$ or article-contributors) to evaluate their "forward- N ing" policy. If the survey shows that it is neither just nor constructive, this novel editorial trend must be nipped in the bud. The "BMF" enjoys an enviable status and assists in setting the moral and practical code for medical professionals. By championing this most unusual and completely unnecessary precedent of making a subset of copyright not inviolate, will the legacy it bequeaths include the first word ("forwar\& ing") of the vocabulary of Newspeak in medicine

Vinod Kumar Gupta, $M B, B S, M D$ (Internă Medicine) is Medical Officer/Physician in the Dubai Police Medical Services, in the United Arab Emirates.

\section{References}

1 Dewey ME. Authors have rights too. British Medical fournal 1993; 306: 318-20.

2 Skrabanek P. The ethics and politics of human experimentation. Cambridge: Cambridge University Press, 1993.

3 Gillett R, Harrow J. Is medical research well served by peer review British Medical fournal 1993; 306: 1672-5.

4 Smith R. Questioning academic integrity. British Medical fournal 1994; 309: 1597-8.

5 Bhopal RS, Tonks A. The role of letters in reviewing 옥 research. British Medical fournal 1994; 308: 1582-3.

6 Crosson FJ. Science and literature. Science and contemporary society. Cochin: Palco Publishing House, 1967.

7 Anonymous [editorial]. US science policy: what $N$ science, whose policy? Lancet 1994; 343: 367-8.

8 Gupta VK. Menstrual migraine is not pathogenetically related to premenstrual syndrome. Cephalalgia 1994; 14: 411-2.

9 Rennie D. Editors and authors. Fournal of the American Medical Association 1989; 261: 2543-5.

10 Anonymous [editorial]. On the falsification of ideas. Lancet 1992; 340: 344-5.

11 Orwell G. Nineteen eighty-four. Harmondsworth: Penguin Books Ltd, 1954.

12 Gillon R. Medical ethics: four principles plus attention to scope. British Medical fournal 1994; 309: 184-8.

13 Bhopal RS, Parkin DW. Authors have rights too. British Medical fournal 1993; 306: 716-7. 